\title{
Collaborative research and innovation project for revitalizing the BIM process
}

\author{
Peter Gyuris \\ Geonardo Environmental Technologies Ltd., M.Sc, peter.gyuris@geonardo.com \\ Bese Pal \\ Geonardo Environmental Technologies Ltd., M.Sc, bese.pal@geonardo.com \\ Csaba Benedek \\ Institute for Computer Science and Control Eötvös Lóránd Research Network, Ph.D \\ benedek.csaba@sztaki.hu \\ Zsolt Janko \\ Institute for Computer Science and Control Eötvös Lóránd Research Network, Ph.D \\ janko.zsolt@sztaki.hu
}

\begin{abstract}
The European building stock needs fast and affordable digitalization for facilitating the renovation process to achieve higher energy efficiency in buildings and in houses. Most of the residential buildings built between 1925-1975 lack proper documentation and digital building information, as opposed to newer buildings. Digital building information (geometry and attribute data) is required to plan retrofitting projects or renovations of facades. This work can only be efficient if Building Information Modelling (BIM) is available for stakeholders (owners, architects, contractors etc.). Whereas city planners of municipalities or social housing companies are striving to manage their properties and building portfolio on multiple scales, these stakeholders are seeking an approach that enables spatial planning, efficient asset management and energy consumption and management services for their buildings. In a EUREKA labelled project (E!12649 Ready2BIM) three partners worked together, two from Hungary (Geonardo Ltd. and SZTAKI) and one from Germany (CAALA GmbH).

Key words: Building Information Modelling, Laser Scanning, 3D Point clouds, City Information Model, Web-GIS

\section{Suradnički istraživački i inovacijski projekt za revitalizaciju BIM procesa}

Sažetak: Europskom fondu zgrada potrebna je brza i pristupačna digitalizacija kako bi se olakšao proces obnove radi postizanja veće energetske učinkovitosti u zgradama i kućama. Za razliku od novijih zgrada, većina stambenih zgrada izgrađenih između 1925. i 1975. godine nema odgovarajuću dokumentaciju i digitalne podatke o izgradnji. Za planiranje projekata rekonstrukcije ili obnove fasada potrebni su digitalni podaci o zgradi (geometrija i podaci o značajkama). Ovaj posao može biti učinkovit samo ako je zainteresiranim stranama (vlasnicima, arhitektima, izvođačima itd.) na raspolaganju BIM (eng. Building Information Modelling). Dok urbanisti općina ili poduzeća za socijalne stanove nastoje upravljati svojim nekretninama i portfeljem zgrada na više razina, ove zainteresirane strane nastoje pronaći pristup koji omogućuje prostorno planiranje, učinkovito upravljanje imovinom, te usluge potrošnje i upravljanja energijom za svoje zgrade. U projektu s oznakom EUREKA (E!12649 Ready2BIM) zajedno su radila tri partnera, dva iz Mađarske (Geonardo Ltd. i SZTAKI) i jedan iz Njemačke (CAALA GmbH).

Ključne riječi: Building Information Modelling, lasersko skeniranje, 3D oblaci točaka, informacijski model grada, Web-GIS

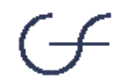


Gyuris, P., Pal, B., Benedek, C., Janko, Z.

Collaborative research and innovation project for revitalizing the BIM process

\section{INTRODUCTION}

Large-scale commercial and institutional construction projects show a BIM usage rate of more than $50 \%$, however BIM is only used in $7 \%$ of all residential projects - as in practice BIM implementation in residential projects is inefficient therefore the market is open for innovative solutions. This project delivers an innovative software product (Ready2BIM online platform) and related services on building surveying and sustainability assessment for the emerging "digital" reconstruction market. The online platform is a complementary and an innovative toolset for refurbishment project in building and district retrofit assessments and planning, combining the potential of Building Information Modelling (BIM) by allowing architects and planners work on multiple scales and on multiple buildings with a sufficient number of data and information collected on buildings and districts.

One of the major strengths of the online platform is the ability to connect with other services - on and offline - to support further comfort of the end users by a "one-stop shop" approach. To achieve this, the platform has developed APIs so third-party services, for example other online software, can be integrated to enable the building modelling. Also, direct connection to free Web-GIS data is part of the application, by default, allowing to import existing geometric data e.g. building footprints or outlines.

\subsection{Background}

The online platform builds on several industry standards and technical functions. The platform is an ecosystem of technologies that are used today in building design, constructions and city planning.

Interoperability is key in the AEC industry (Architecture, Engineering, Construction). The BuildingSmart community is the leader of openBIM that is created to produce data standards for industry. The most important product is the definition of a data scheme that represents buildings digitally, both geometrically and with attribute information. Their published international data scheme is the ISO Industry Foundation Classes (ISO IFC) that can be used to exchange building information between software and/or online applications. This helps collaborative work among several industry specialist and disciplines for instance architects, mechanical engineers, electrical engineers etc.

BIM Level 1 establishes a methodology for managing construction information, including that generated by CAD systems, using a disciplined process for collaboration and a specified naming policy. It can be used as a basis by all the intervening parties during all stages of the project, including the supply chain. BIM Level 2 requires the definition of file-based deliverables using a common data environment (CDE). These files can be architectural, energy models or spreadsheets reports (among many others). However, BIM Level 2 takes a step forward and deploys the concept of "intelligent libraries" and "intelligent models".

Dynamic Simulation Modelling, Geographic Information Systems (GIS), cloud data storage \& analysis, KPIs and optimization / value analysis tools, based on different backend software tools, have been conceptualized in FASUDIR project of which Geonardo was a consortium partner. The different renovation measures are taken from a repository of technologies that is a result of previous research projects and represents the current retrofit measures (RES application, insulation etc.).

3D building modelling has two major aspects, the geometrical modelling of a building and a semantic modelling that in all cases enhances the geometric models with building attribute information e.g. wall width, type of roof etc. In the past 5-10 years geometric and semantic models became widespread e.g. CityGML (base for INSPIRE building data scheme), architectural models used in Autodesk (.RVT), Nemetschek (.pln) etc. 
Gyuris, P., Pal, B., Benedek, C., Janko, Z.

Collaborative research and innovation project for revitalizing the BIM process

The challenge was to form a comprehensive IT system as a framework that handles the various data schemes yet it proves to be efficient to use for assimilating information to serve engineers, contractors etc. for building and retrofit design.

\section{CONCEPT}

The existing prototypes and technologies possessed by the project consortium were not linked to each other and are using different file formats, data baselines and work on different scales. While the FASUDIR prototype was designed for city and district level assessments, the CAALA tool and 3D-modelling algorithms are mainly applicable on building level only. During the Ready2BIM project, the different technologies were enhanced with new functionalities and linked together in one online platform as a single ecosystem of tools. Thus, the interaction of the different modules on multiple scales allow a much more advanced planning and evaluation of the built environment in a single tool. The platform therefore allows linking different data sources for data capturing and advanced analysis with the cloud (e.g. big data, processing analogue floor plans and energy bills, drones, pointclouds etc.). The online platform further developed to accommodate multiple types of building information such as architectural data e.g. drawings, CAD/IFC and standard 3D file formats. Also attribute information such as building type, construction year, billing information etc. was to be incorporated; all that is important to plan retrofitting projects with cost calculation and return on investment. Moreover, the platform allows managing all information integrated and providing various services for owners in managing their building portfolio (asset management). The Ready2BIM platform supports spatial planning by incorporating GIS data (INSPIRE/CityGML European standard), allow to manage high resolution 3D city model using drone imagery and 3D laser scanning for custom operations via the participating SMEs commercial service portfolio.

The research and innovation action on 3D building modelling, BIM database integration with City Information Model (GIS) facilitate to provide multiple services on the construction market and connect with more market players in the construction and online services sector.

\subsection{Research objectives}

The project is based on the following main development phases:

At the beginning all the necessary definitions and baseline research for the architecture of the new online platform has been defined and developed: the architecture of the new online platform, which defines all the interoperability requirements of the different modules and how these modules (e.g. FASUDIR prototype and the CAALA tool) can be connected to each other and work together. Also the new modules for smart algorithms for 3D-model creation on building level was planned and connected in order to allow the BIM process in the tool to run on building level. Moreover, the necessary data requirements for the interaction of all software modules and data formats are defined (data sources, levels ofdetail, scales, etc.)

The online platform was further developed to accommodate multiple types of building information such as architectural data e.g. drawings, CAD/IFC and standard 3D file formats. Also attribute information such as building type, construction year, billing information was to be incorporated; all that is important to plan retrofitting projects with cost calculation and return on investment. All necessary default databases have been defined and set up.

In Phase 2 the implementation and programming of the new online-platform was to be conducted: The interfaces for the connection of the different data formats and existing 
Gyuris, P., Pal, B., Benedek, C., Janko, Z.

Collaborative research and innovation project for revitalizing the BIM process

modules (FASUDIR prototype, CAALA tool, 3D modelling algorithms, etc.) was to be set up and integrated in the online platform back-end. All the external services (e.g., Web-GIS server, open data sources, APIs) are planned to be connected to the online platform. A userfriendly and graphical user-interface based on a 3D-map was planned to allow the users a quick and easy interaction with the online-platform.

\section{IMPLEMENTATION}

\subsection{Online building manipulation tools}

The Ready2BIM platform supports activities in the following phases:

- City modelling: by accessing OpenStreetMap data through the map-based user interface or by uploading GIS data a complete city model can be set up.

- Region level analysis: on buildings of a city model all the performance indicators get automatically calculated and displayed to the user.

- Building level analysis: single buildings are available as downloadable IFC models for further analysis in external tools (e.g. CAALA tool). Results produced by the CAALA tool are imported in JSON data format. A dedicated section of the API is published for supporting the integration of the CAALA tool to the platform.

- Reporting: region and building level results be available as XLSX exports.

Browsing publicly available data:

Visitors are allowed to access public city models. The primary data representation is a map where geographical reference data is displayed (e.g. streets, buildings).

The following functions support the user to access the information of interest:

Searching for location using Google Geolocation API,

Searching for building by address.

After searching for a location or building, by clicking on a building its information sheet is open summarising the general details along with the associated performance indicators and evaluation results, displayed on charts (e.g. line chart for time series data).

Data displayed on the information sheet is available as downloadable spreadsheet in XLSX format.

Building activation:

Users, in the city modelling phase, can activate buildings, that is the procedure of adding new buildings to the city model by uploading footprint data in ESRI Shapefile or GeoJSON data format. Alternatively, users can activate buildings using the OpenStreetMap layer displayed as the base layer of the map.

The Data Entry Wizard coordinates the building activation process which consists of the aforementioned building footprint data collection and a simplified method for setting up building attribute values.

All registered users are allowed to activate buildings in their city models.

Energy simulation:

All simulations run automatically after a building got activated.

Data analysis:

Specific tools for data analysis are available on the user interface. These tools operate on selections, in other words on multiple buildings filtered by some selection criteria.

Selection helper:

Users can edit individual buildings and series of buildings for completion and modification of the city model. In order to facilitate this process, a selection helper is designed to refine object (e.g. building) selection and perform multiple selections. Selection helper focuses on 
the building and district object(s) subject to analysis (KPIs), changing attributes and applying interventions.

Defining selections:

The figure 1 shows how to choose a building by clicking on a building object and clicking on the "selection" button. This method of choosing a building works using the map.

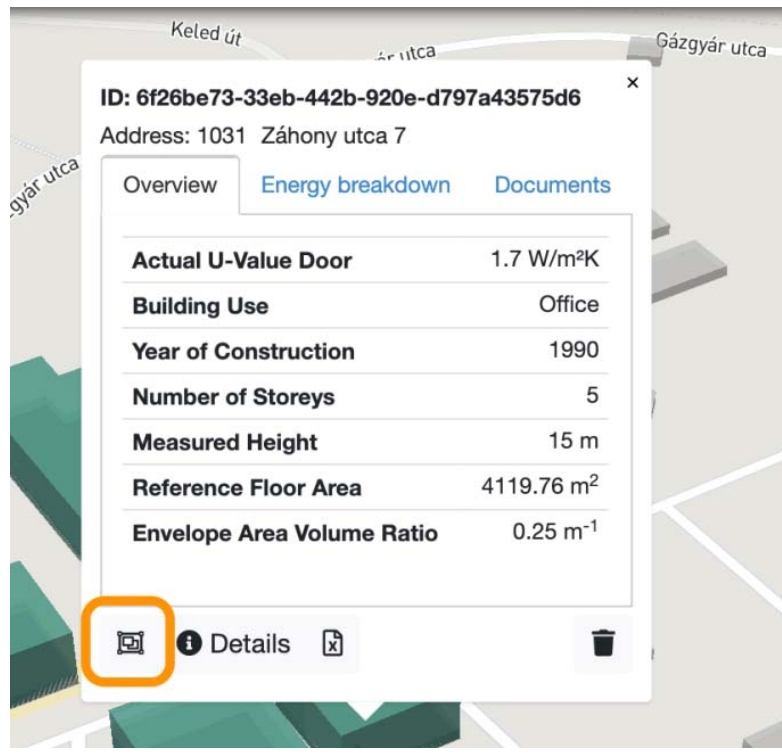

Figure 1. Add building to the selection

Once a building is selected it appears as a criterion on the selection helper panel with its unique ID and attributes.

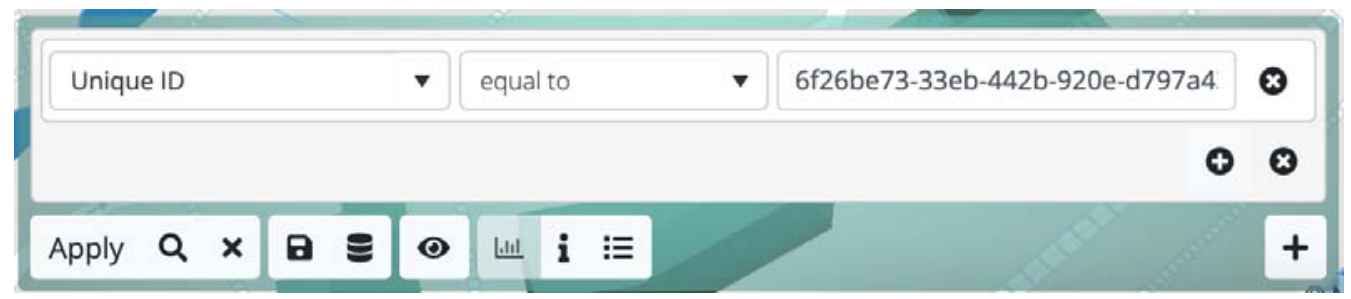

Figure 2. Selection helper

There is another way of setting up selections. On the selection helper panel, complex criteria can be set up by defining criterion groups that contain individual criteria against specific building attributes of energetic characteristics. 
Gyuris, P., Pal, B., Benedek, C., Janko, Z.

Collaborative research and innovation project for revitalizing the BIM process

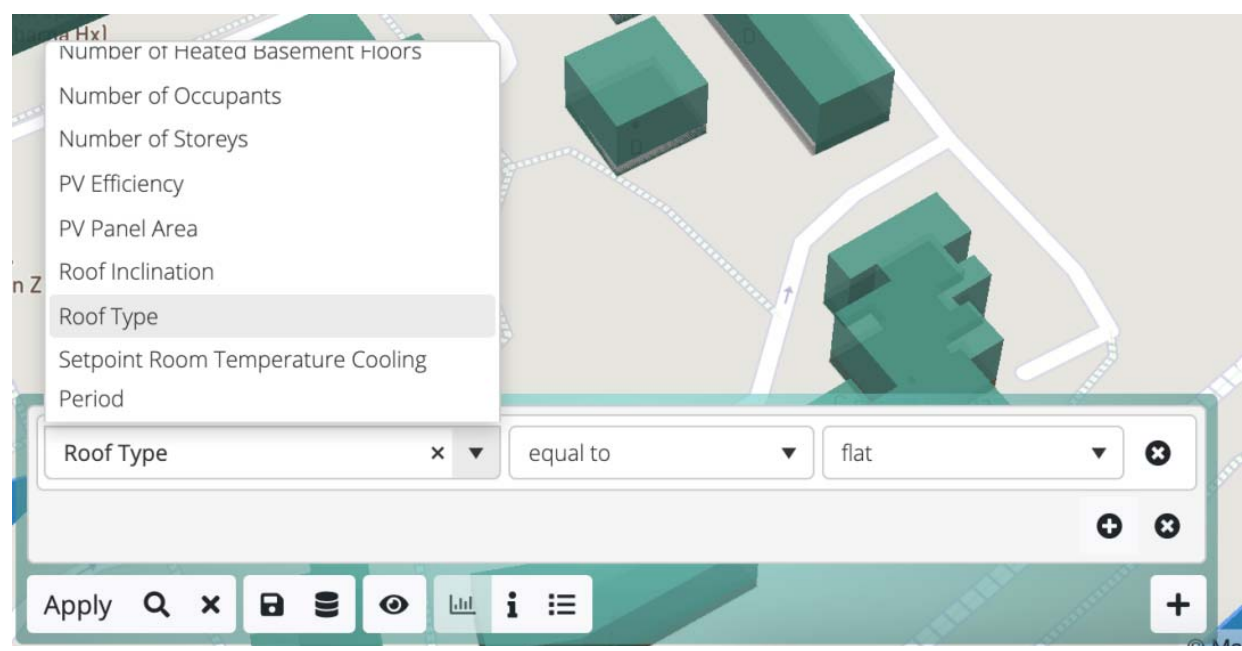

Figure 3. Example of a custom selection criteria

Data manipulation:

Building details, such as "number of storeys" or "heritage status", are attributes that are important for setting up the correct status of the model; they are therefore allowed to be checked and edited.

Attribute editor:

Building attributes stored on the building model are serving as input for the geometric and energetic simulation. Each building attribute can be listed on the panel of Attribute Editor for editing.

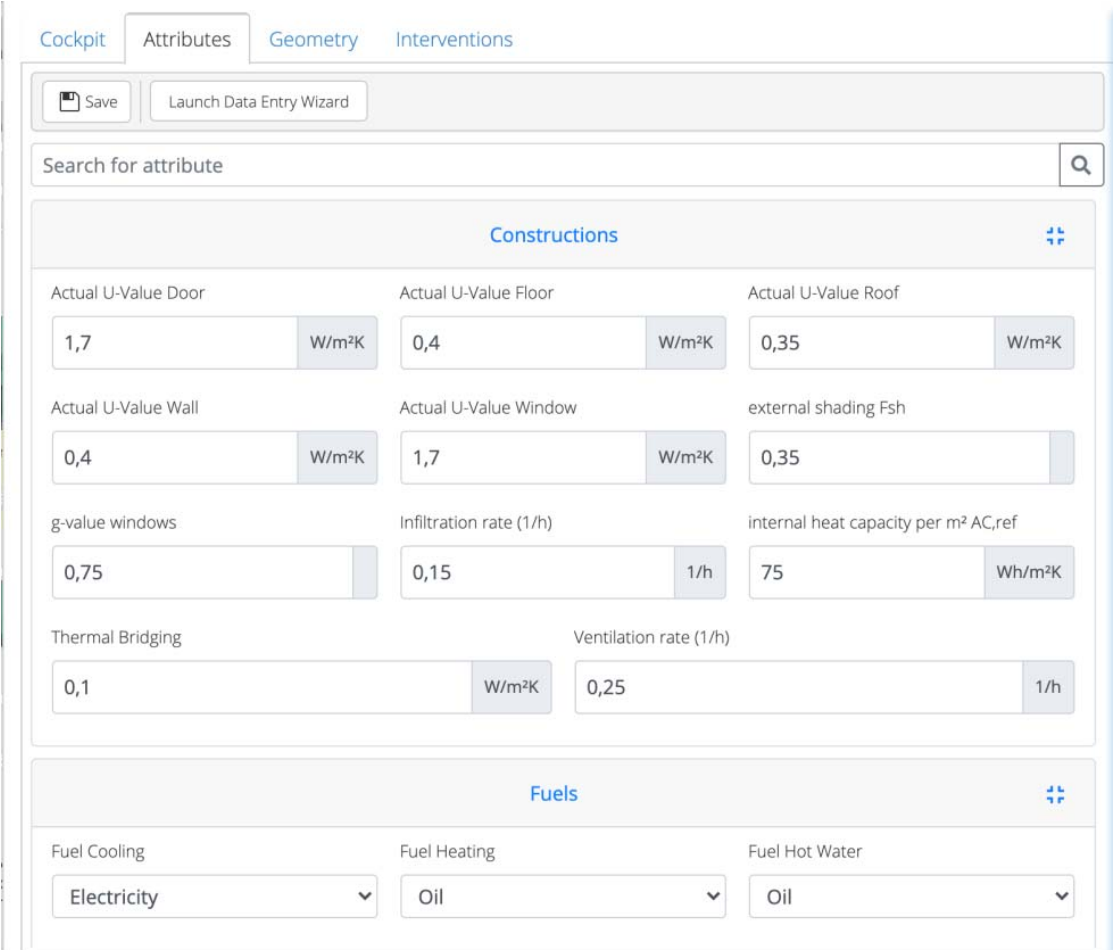

Figure 4. Attribute Editor panel 
Gyuris, P., Pal, B., Benedek, C., Janko, Z.

Collaborative research and innovation project for revitalizing the BIM process

By clicking on Save the city model gets updated and all the relevant simulations can run. There are attributes that affects the geometric characteristics as well e.g., number of storeys.

KPI Analysis Tool:

This tool allows users to inspect the buildings and districts performance against criteria that exist in current evaluation methods from the environmental, economic and sustainability point of view. After applying a selection, the KPI Analysis Tool can display the aggregated results on charts and in tabular format as well.

\subsection{Online building façade analysis tools}

In this chapter, we discuss the developed tool applicable in the conceptual design phase of a building retrofit project for the collection of façade information with high precision via laser scanning. Subsequently, using the analysis functions on the 3D point cloud, surfaces are ready for insulation and the volume of the material can be calculated.

At the platform, following the launch of the façade analysis tool, one can upload a point cloud, and at the same time, the buttons that allow segmentation appear in the control panel.

The user can start segmentation (plane detection) with two separate buttons. In the first case, the algorithm runs with default parameters. In the second, a window comes up where the tool asks for three parameters: a threshold for the curvature and smoothness of the surface, and the smallest leaf elements in the voxel-structure.

After successfully running the segmentation, a coloured point cloud is visible, where different colours represent different planes (wall segments).

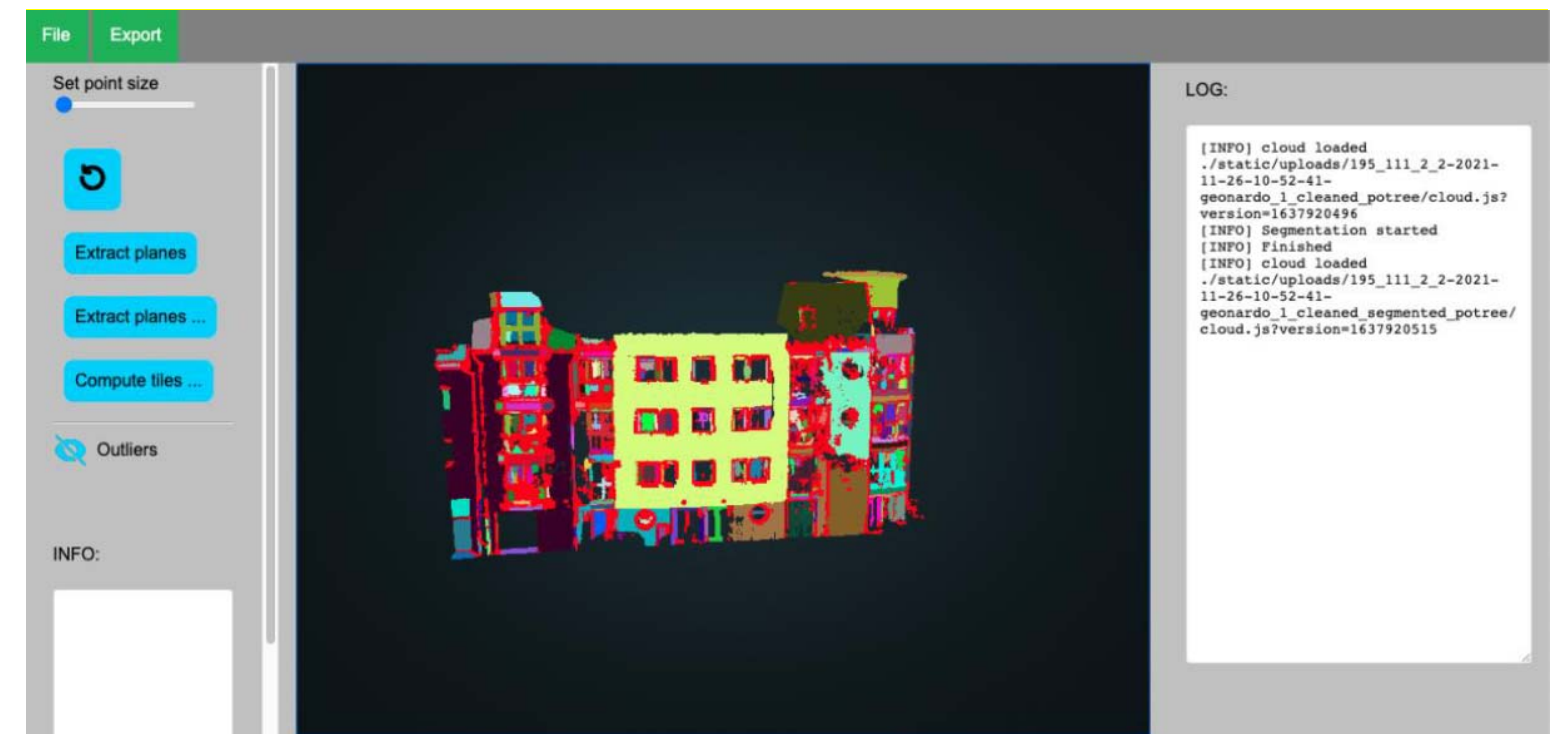

Figure 5. Segmented walls of several buildings

On the segmented point cloud, you can select individual walls, even several at a time. You can then "tile on" selected segments by pressing the Compute tiles button, after which a window will come up where you can specify the size of the tiles. Tiles can be rectangular as well. 
Gyuris, P., Pal, B., Benedek, C., Janko, Z.

Collaborative research and innovation project for revitalizing the BIM process

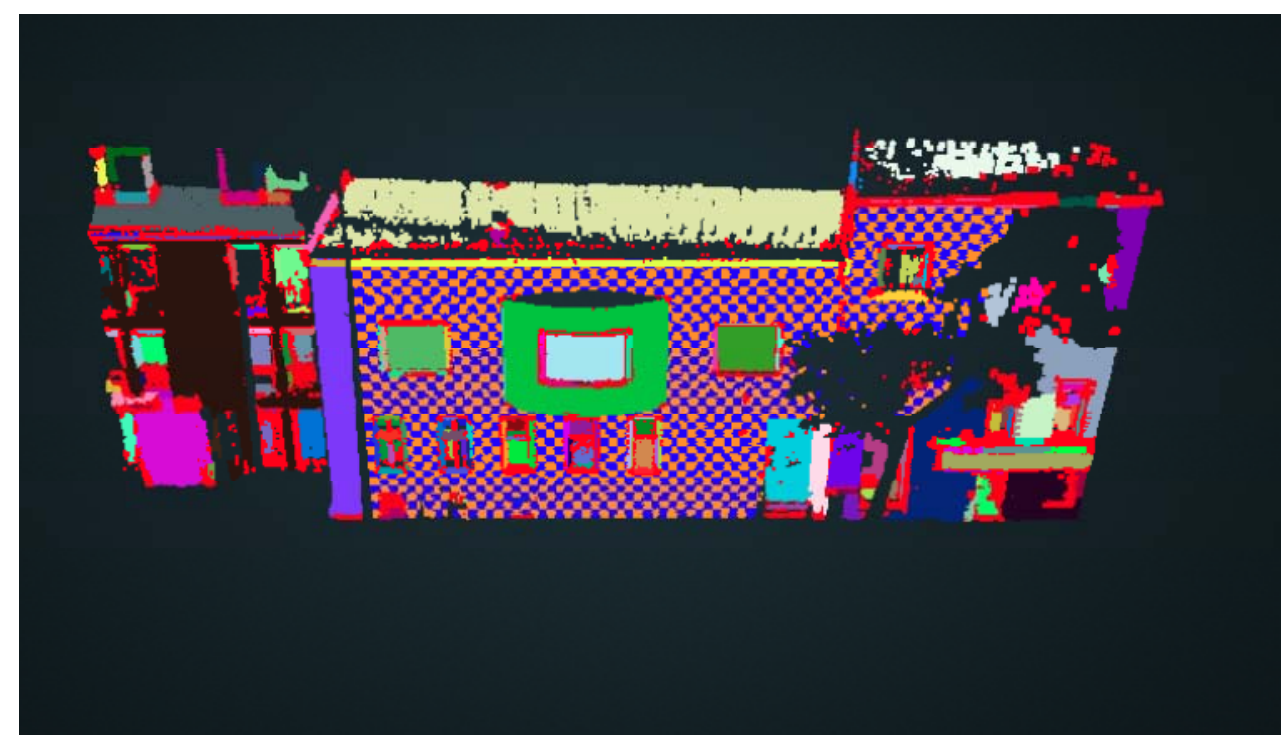

Figure 6. Tiled building façade

Tiling numerical data is displayed at the bottom of the control panel:

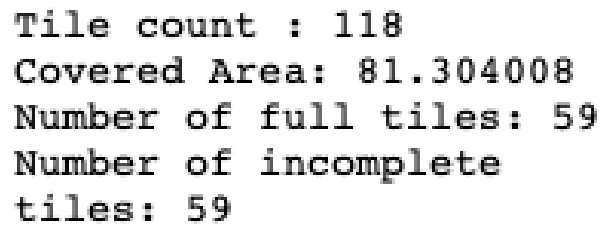

Figure 7. Information block about the tiled building façade

The results of each step (segmentation and tiling) can be saved in the Export menu item. The user can always save the result of the actual step. The point cloud is available in PCD or PLY format, optionally, while the vector model resulting from tiling is given in PLY format. The tiles could represent the insulation panels in a retrofit action, which in this tool take only a few seconds to plan and calculate for volume and cost assessments of a building retrofit project.

\section{CONCLUSIONS}

Ready2BIM provide a comprehensive software product that comprise a set of tools for building and city modelling, data processing and management and retrofit design planning and the simulation of key metrics from several dimensions (energy demand, share of renewables, carbon emissions, cost efficiency, environmental quality, health and wellbeing, mobility, etc.). The Ready2BIM tool is unique as it enables planners to work on multiple dimensions. Therefore for the new web-toolkit the following main results are: (i) a cloudserver, which holds old the geometric and semantic data for the different building, district and city objects, (ii) tools developed to allow planners to assess the different defined key metrics aka KPls for several dimensions to assist them in planning future renovations, (iii) a new smart model generation function for buildings is implemented, which allows connecting different data sources and also extern services via APIs to semi-automatic or fully automatic created 3D-building models and all needed geometries, (iv) data collection and building 
Gyuris, P., Pal, B., Benedek, C., Janko, Z.

Collaborative research and innovation project for revitalizing the BIM process

inspection services for municipalities and real estate owners, (v) digitalization of the building stock and consultancy in implementation of BIM and CIM processes in municipalities and private owners.

\section{Acknowledgement}

The Ready2BIM consortium thanks for the support of the Hungarian Government's National Research Innovation (NRDI) Fund. Ready2BiM project is financed from the NRDI Fund. Contract number: 2018-2.1.3-EUREKA-2018-00032.

\section{REFERENCES}

1. Schuhmacher S., Böhm J. Georeferencing of terrestrial laserscanned data for applications in architectural modelling, University of Stuttgart, Institute for Photogrammetry, Germany, 2005

2. Lee, S.M.; Joon I.J.; Lee, B.H.; Leonessa, A.; Kurdila, A. A real time grid-map generation and object classification for ground based 3D Lidar data using image analysis techniques. Proc. IEEE International Conference on Image Processing (ICIP), 2010

3. Papon, J. et al. Voxel cloud connectivity segmentation - supervoxels for point clouds. In: IEEE Conference on Computer Vision and Pattern Recognition (CVPR), 2013, pp. 20272034.

4. Chmielewski, Sz., Tompalski, P. Estimating outdoor advertising media visibility with voxelbased approach. Applied Geography, 2017, no. 87, pp. 1-13,

5. Marton Z.C., Rusu R.B., Beetz M. On Fast Surface Reconstruction Methods for Large and Noisy Datasets, Proceedings of the IEEE International Conference on Robotics and Automation (ICRA), May 12-17, 2009, Kobe, Japan

6. European Commission Joint Research Centre D2.8.III.2 Data Specification on Buildings Technical Guidelines (EC), December 10, 2013, INSPIRE Knowledge Base

https://www.ukbimframework.org/ (last visited 09.12.2021)

https://technical.buildingsmart.org/standards/ifc/ (last visited 09.12.2021) 